\title{
Improvement of Reliability and Ecological Safety of NPP Reactor Coolant Pump Seals
}

- Shevchenko Serhii, PhD in Technical Sciences

Pukhov Institute of Modeling Issues in Power Engineering, National Academy of Sciences of Ukraine, Kyiv, Ukraine

ORCID: https://orcid.org/0000-0002-5425-9259

- Shevchenko Oleksandr

Sumy State University, Sumy, Ukraine

ORCID: https://orcid.org/0000-0003-4039-940X

The paper presents the analysis of existing designs of NPP reactor coolant pumps (RCP) rotor sealing systems. The most common design solutions of sealing units that provide the necessary tightness, reliability and service life under high pressure, temperature and sliding speeds typical for RCP, as well as trends for their improvement to increase tightness and environmental safety of activities were identified.

Designs of impulse seals with a self-adjusting clearance are presented as the most promising assemblies for sealing pump shafts with high parameters. A computer model of impulse mechanical seal as an automatic control system is proposed. A framework for calculating impulse mechanical seals has been developed, allowing the choice of their main geometric parameters to ensure the optimal value of the mechanical clearance and the friction moment on the sealing contact surfaces. Expressions are obtained for constructing the static and flow characteristics of a impulse mechanical seal, the condition for its dynamic stability is determined. The paper presents the shaft sealing system of RCP, main nodes of which are several stages of impulse mechanical seals with a self-regulating clearance.

Keywords: RCP shaft seals, environmental safety, seal model, automatic control system, static calculation.

(c) Shevchenko S., Shevchenko O., 2020

\section{Introduction}

NPP reactor coolant pumps (RCP) play a vital role: pump the coolant (water) from the reactor core under high pressure, temperature and induced radioactivity and to a large degree determine reliability and steadiness of reactor operation. Failures and malfunctions are unacceptable, as they directly affect industrial and environmental safety [1].

In RCP design, the shaft seal assembly is the most important component on which pump reliability, durability and, consequently, operational preparedness and environmental safety of the entire unit depends on. Seals should ensure the necessary tightness in pump operation in various operating and emergency modes. External leaks of primary radioactive water through seals should not exceed a few cubic centimeters per hour, and controlled leaks of seal (purified) water: $0.5-1.0 \mathrm{~m}^{3} /$ hour. Flow rate of seal water inside the pump should also be limited. The shaft seal should remain operational after a short-term de-energization of the pump power supply system, which may result in the termination of locking and cooling water supply. Regarding reliability, the sealing system should not be worse than other pump assemblies and should operate for several years without replacement.

Developing shaft seals for high-power RCPs is a complex technical task and is a subject of research of many leading pump manufacturing companies. Despite the fact that signifficant experience has been accumulated in commercial operation, the issue of developing sealing systems with high reliability, tightness and long service life remains relevant. 


\section{Problem definition}

The the objective of this work is to design a reliable sealing system for RCP shaft that ensures tightness and environmental safety.

The following tasks were set to achieve this objective:

based on the analysis of existing designs of RCP seal shaft, identify the most promising areas of their design;

develop a model and a computational method for a seal with a self-regulating gap as an automatic control system.

\section{Overview of existing sealing system designs}

Figure 1 shows a three-stage RCP mechanical seal in which a uniform pressure distribution is achieved between the stages by throttles installed on the external line [2]. Pressure separation is accompanied by continuous leaks through the external line, with a rate of up to several hundred liters per hour. The heat released from the friction of contacting surfaces is removed through a special closed circuit with a heat exchanger and a filter to trap wear products. Circulation in the cooling system is formed by the axial labyrinth pump (impeller) built in the seal.

To ensure an adequate seal tightness in emergencies when one of the stages fails, each of them is designed for the full pressure differential. The main seal components are an axial movable bushing and a fixed support ring constantly pressed to each other by medium pressure and springs.

Based on mechanical seals, a number of designs was developed, in which sealing bands are unloaded and operate with a small gap in the modes of friction close to liquid. They include hydrodynamic and thermohydrodynamic seals.
In hydrodynamic seals, in addition to sealing bands typical for mechanical seals, there are additional support surfaces with wedges that get narrow in the tangential direction and are separated by grooves (Figure 2, a). When the shaft rotates, an additional hydrodynamic force occurs on wedgeshaped surfaces, which is inversely proportional to the gap squared. The balance of the axially movable bushing is automatically maintained by changing the force on the wedges when the gap deviates from the optimal value. During stoppage, the seal closes and provides tightness. In addition to slopes, hidden Rayleigh steps (Figure 2, c) or spiral grooves (Figure 2, d) can be used to create lifting force [3]. However, these seals are not widely used in coolant pumps due to a complex manufacturing technique, especially when materials with high hardness are used in friction pairs.

The operation principle of thermohydrodynamic seals is based on using deformation of the rings under the impact of thermal stress in the contact zone. Crescent-shaped grooves on the surface of one of the rings (Figure 2, b) promote formation of micro-wedges resulting from uneven cooling of ring operating surface in the circumferential direction. In the zone of micro-wedges, additional lifting forces occur during rotation, which can significantly reduce the contact pressure on the operating surfaces and friction coefficient. The advantage of these seals is that as the sliding speed and pressure differential increase, the temperature difference between certain sections of the operating surface increases. Under the impact of high thermal stress and deformations it causes, the zones with microwedges expand, lifting forces increase and friction coefficient in the operating gap decreases. During stoppage, a thermohydrodynamic seal provides full tightness, as there are no surface deformations caused by additional thermal stress.

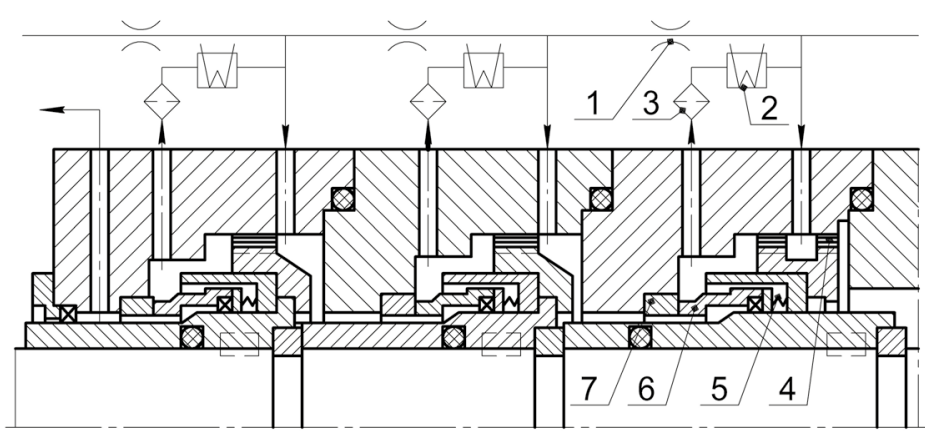

Figure 1 - three-stage mechanical seal:

1 - throttle; 2 - heat exchanger; 3 - filter; 4 - impeller; 5 - spring; 6 - axially movable bushing; 7 - support ring

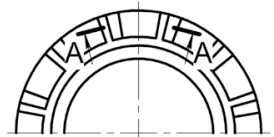

a

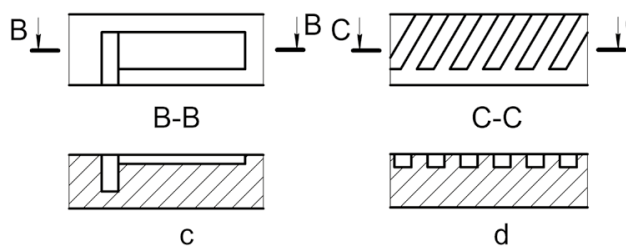

Figure 2 - Variants of mechanical seals: $\mathrm{a}$ - hydrodynamic seal; $\mathrm{b}$ - thermodynamic seal; c- Rayleigh step; $d$ - spiral grooves 


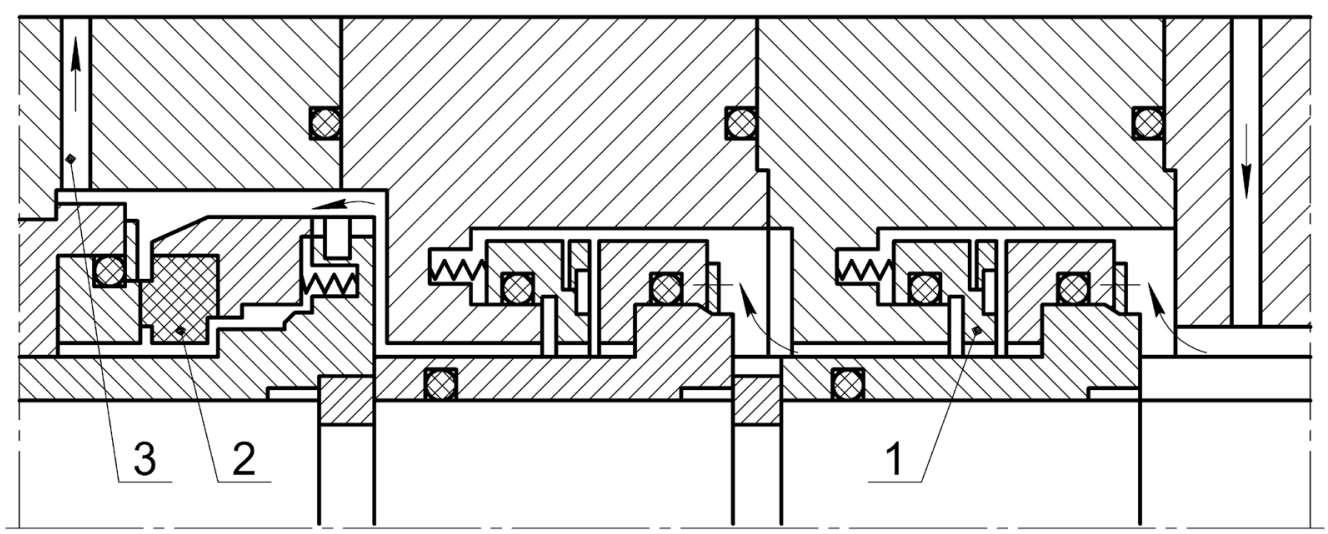

Figure 3 - Combined seal of RCP shaft at NPP with water-cooled water-moderated reactor

The design for coolant pumps manufactured by KSB (Figure 3) [4] is an example of using thermohydrodynamic seals.

In coolant pumps with a full pressure differential of 9.5 MPa, KSB uses dual thermohydrodynamic seals 1 and 2 (Figure 4), between which the pressure is divided in half by throttles 3 and 5 under controlled leaks of $0.5 \mathrm{~m}^{3} /$ hour through them. The emergency stage of seal 4 is a mechanical seal, which remains open under normal conditions due to springs.
If stage 2 fails and external leaks through it increase, the emergency seal closes due to occurred pressure differential and provides the necessary tightness of the entire assembly both in the case of pump rundown and if it stops.

Continuous design improvement for thermohydrodynamic seals allowed using combined seal assemblies in some coolant pumps, in which the last and next to the last stages are thermohydrodynamic [5].

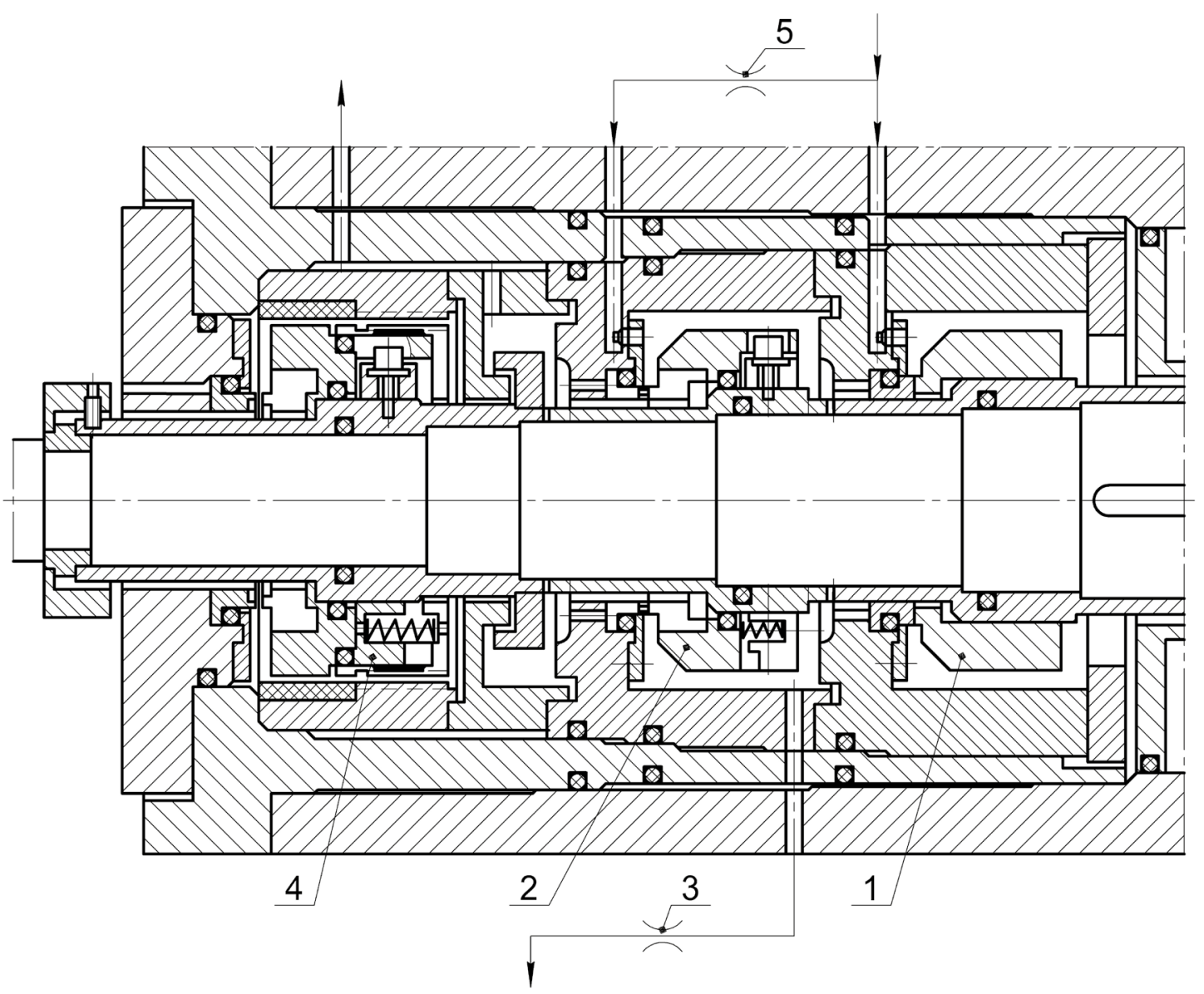

Figure 4 - Combined seal of RCP shaft 


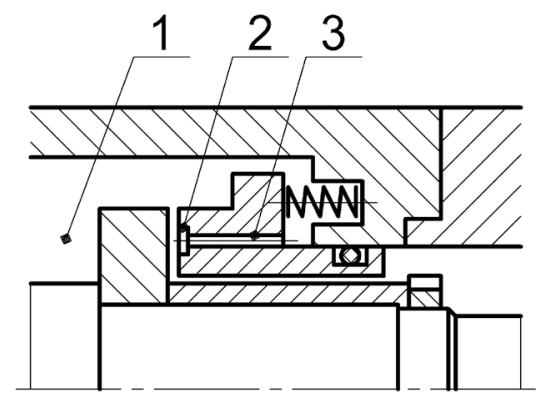

a

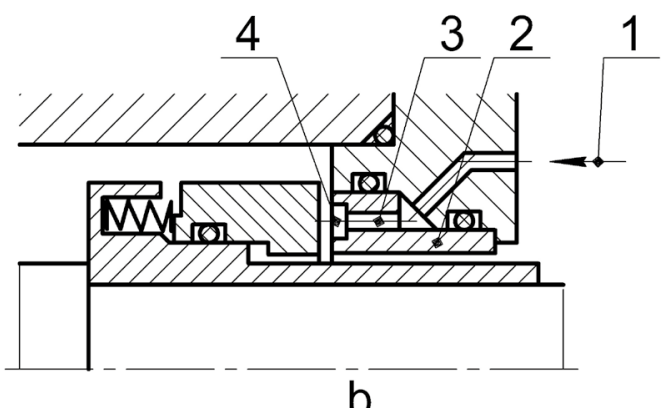

b

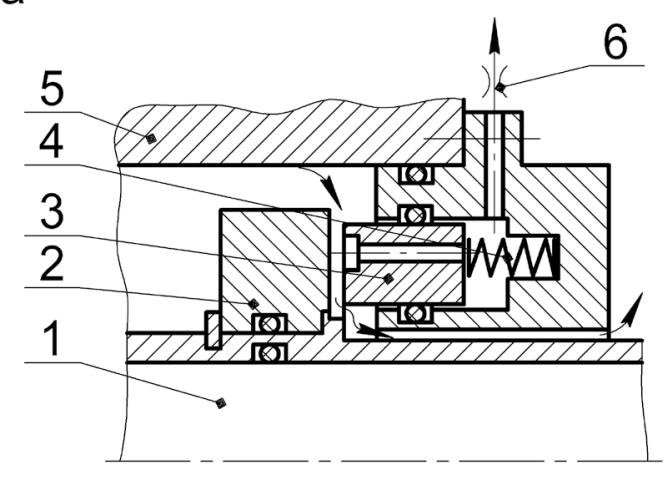

C

Figure 5 - hydrostatic seals: a - with fixed gap; $b$ - with regulated gap; $c$ - with controlled leaks

Under high pressure differential and rotational speed, when it is required to provide a long service life and insignificant leaks are allowed, seals with a continuous liquid film are increasingly used. They include hydrostatic seals consisting of the same components as conventional mechanical seals. To form a guaranteed gap between sealing surfaces (Figure 5, a), closed chambers 2 are made on one of them, which are connected through throttles 3 to cavity 1 . Axial gap size depends on the size of throttles, chambers as well as force of springs. The throttles are a correcting member and provide selfregulation of the axial gap. When the gap decreases, pressure profile in the opening increases, and when the gap increases, the pressure decreases. To limit leaks through seals and to ensure self-regulation of the axial gap between the sealing surfaces, the throttles should have a high hydraulic resistance and therefore, are made with a very small crosssection (capillary). A significant disadvantage of capillaries is their tendency to clogging and erosion wear. In such cases, normal operation of seals is disrupted.

Figure $5, b$ shows the design of a hydrostatic seal with a self-regulating axial gap [6], in which hydrostatic pressure from external source 1 is used to separate the operating surfaces. Water under high pressure is supplied through capillaries 3 to the cavities of chambers 4 made on fixed ring 2 .
Axial gap size depends on water flow rate through the capillaries. The seal allows separation of the operating surfaces before shaft rotation, and also, if necessary, regulation of water supply to seal cavity changing thereby the axial gap between the operating surfaces. Disadvantages of such seal include possible damages of the external pressure support system, sensitivity to liquid contamination degree, to thermal transients and to changes in the throttle characteristics due to clogging or erosion.

A hydrostatic seal with intermediate pressure extraction (Figure 5, c) [7] manufactured by Hayward Tyler (UK) is of interest. The main seal components are: ring 2, which rotates together with shaft 1; and axial component (piston) 3 installed in casing 5 . An annular groove connected by channels to the intermediate chamber is made on the operating end surface of the piston. Spring 4 ensures the primary contact between ring 2 and piston 3. Seal operation principle is based on the fact that the controlled axial gap between the sealing surfaces is automatically maintained by external throttle 6 . If the gap increases, the pressure in the chamber behind the piston increases, which causes hydraulic downforce increase. As the axial gap is reduced, the pressure behind the piston decreases resulting in seal opening. Depending on the parameters of seal and throttle components, the piston is installed in balanced position under a certain axial gap. 
Flowserve Corp (USA) developed a hydrostatic seal (Figure 6) with constant leaks. The seal consists of disk 1 located on shaft 12 and axially movable bushing 11 , which is mounted in body spacer 4 . Smooth sealing belt 10 and support support shoe 9 are installed on the end disk surface. Piston 5 is fixed on bushing 11 from the side of low-pressure chamber 7. Throttle 6 is located on the line of controlled leak drain. The chamber formed between piston 5 and housing spacer plate 4 is connected to the atmosphere by channel 3. External leaks on the shaft are limited by the auxiliary stage of mechanical seal 8 . Seal operation principle is based on the fact that during rotation between the disk and axially movable bushing, an axial gap is formed through which controlled leaks come from high pressure cavity 2 to chamber 7 . Due to resistance of throttle 6 , certain pressure is set in chamber 7, which affects piston 5 and bushing 11 that reduces the axial gap and, consequently leaks. As leaks decrease, the pressure in chamber 7 decreases slightly and the reverse process occurs. By selection of relevant geometric dimensions of the main sealing components, it is possible to provide constant leaks, which are automatically maintained by the hydraulic force acting from the low-pressure side [8].

Simplicity of the design and absence of external pumps makes this seal promising for application in $\mathrm{RCP}$, however because of large dimensions it is more sensitive to temperature deformations.

Hydrostatic seals, whose operating surfaces include either the Rayleigh stage, constrictor capability or their combination are sometimes used for automatic maintenance of a certain gap between the operating seal surfaces due to pressure profile change. Such seals are simple in design and do not require additional systems. Their disadvantages: lack of leveling moment and increased sensitivity to wear, since the size of the step and slope is about a few dozens of micrometers.

In hydrostatic seals, leaks through the axial gap are almost independent of the relative rotation of the sealing rings and are determined by pressure differential. Therefore, leaks remain the same

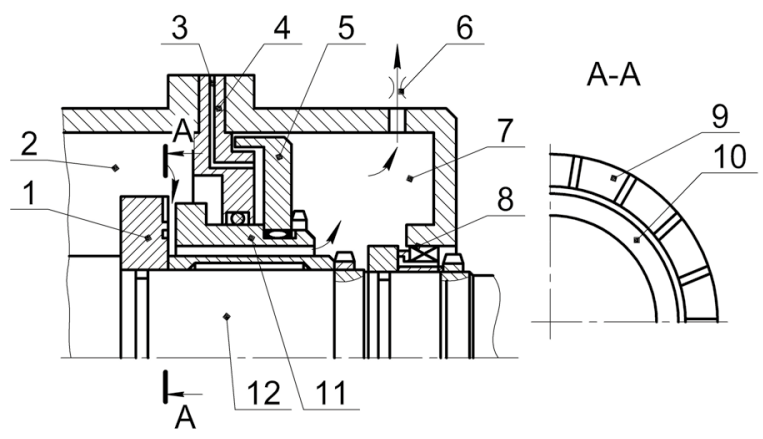

Figure 6 - Hydrostatic seal with constant leaks during stoppage as during pump operation. Thus, it is necessary to install additional stop seals, which makes the design more expensive and complicates operation and repair.

The analysis of the design of RCP rotor seals shows that hydrostatic seals with a guaranteed gap are the most widely used. Such seals provide the necessary tightness, reliability and service life under extreme conditions that are typical for RCP. There are trends to increase sealed pressure differential, reduce the number of sealing stages, simplify auxiliary devices and increase reliability of sealing systems.

\section{Calculation of seals with self-regulated gap}

Impulse mechanical seals as an alternative to mechanical and hydrostatic mechanical seals were developed while designing seals for NPP reactor coolant pumps rotors [1]. Comprehensive experimental studies and field tests have shown that such seals meet stringent requirements for reliability, tightness and service life of the main NPP equipment [2]. Due to this, impulse seals have attracted the attention of developers of high-speed centrifugal machines for other industries [9].

The simplest design of a single-stage impulse seal (Figure 7) differs from a mechanical seal by the fact that closed chambers 2 are located on the end surface of axially movable ring 1 and several radial
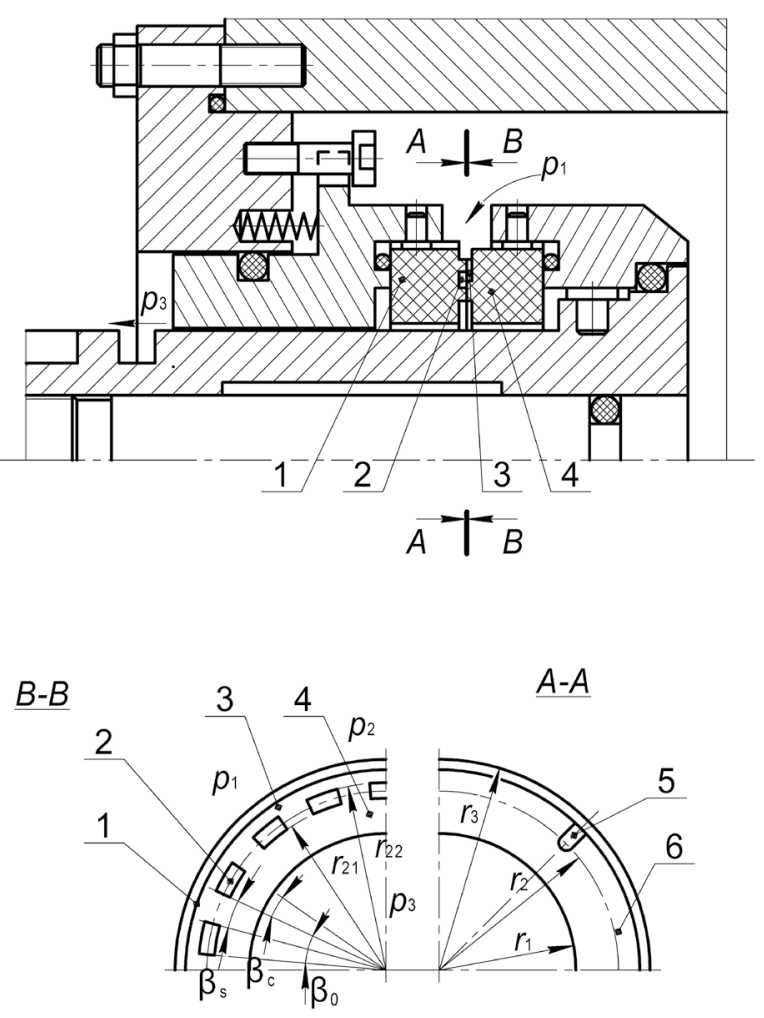

Figure 7 - Diagram of impulse mechanical seal 
feeder channels 5 opened towards the sealed cavity are located on rotating support ring 6 . Through these channels, the sealed medium under sealed pressure $p_{1}$ is injected into the chambers in those short periods $t_{c}=\beta_{c} / \omega$, during which rotating channels 5 pass by chambers 2 . At these moments, pressure $p_{2}$ in the chambers increases abruptly to $p_{2 \max }=p_{1}$ minus inertial pressure $p_{*}=0,5 \rho\left(r_{3}^{2}-r_{2}^{2}\right) \omega^{2}$, which occurs in rotating radial feeder channels. By changing the shape of the feeders, you can change slightly the value of $\mathrm{p}^{*}$ and thus the value of $p_{2 \max }=p_{1}-p_{*}$ The inertial head can be eliminated completely by placing the feeders on a non-rotating ring and chambers on a rotating one.

In order to choose the design parameters that provide the required characteristics of seals in a presented pressure variation range, it is necessary to develop methods for their calculation.

Considering seals in the form of automatic control systems (Figure 8), it is possible to develop a unified approach to their calculation, which reduced to plotting of static characteristics, i.e., dependence of the gap and flow rate on external effects, and determination of static and dynamic stiffness coefficients.

To simplify the calculation, some generally accepted assumptions should be introduced: flow in all throttling channels is assumed to be laminar; friction in secondary seals is neglected, end gaps are considered flat and pressure in them changes according to linear law (Figure 9).

To enhance the feedback between the averaged pressure in the chambers and end gap, tubular feeders can be used, which supply a sealed liquid jet in turns into the chamber (sector $\beta_{c}$ ) and into the end gap (sector $\beta_{s}=\beta_{0}-\beta_{c}$ ).

Taking into account the comments made, a general procedure for calculating impulse seals was proposed. The basic calculation formulas are presented in the Table.

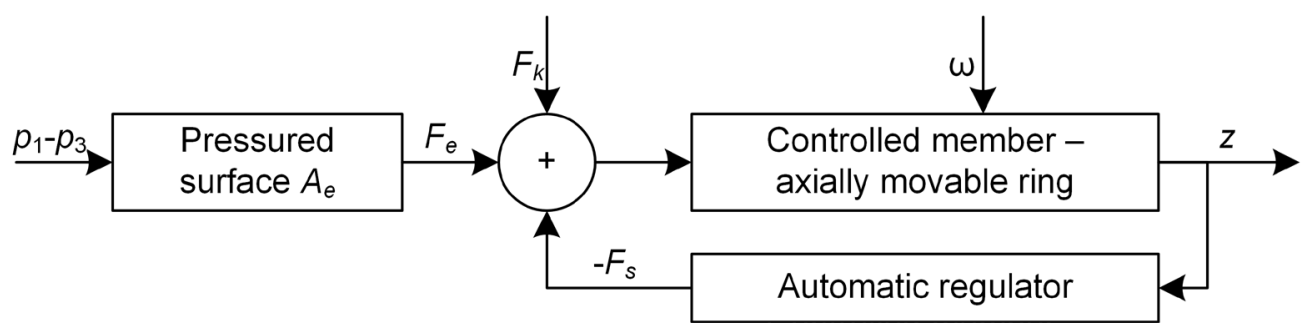

Figure 8 - Model of impulse seal as an automatic control system
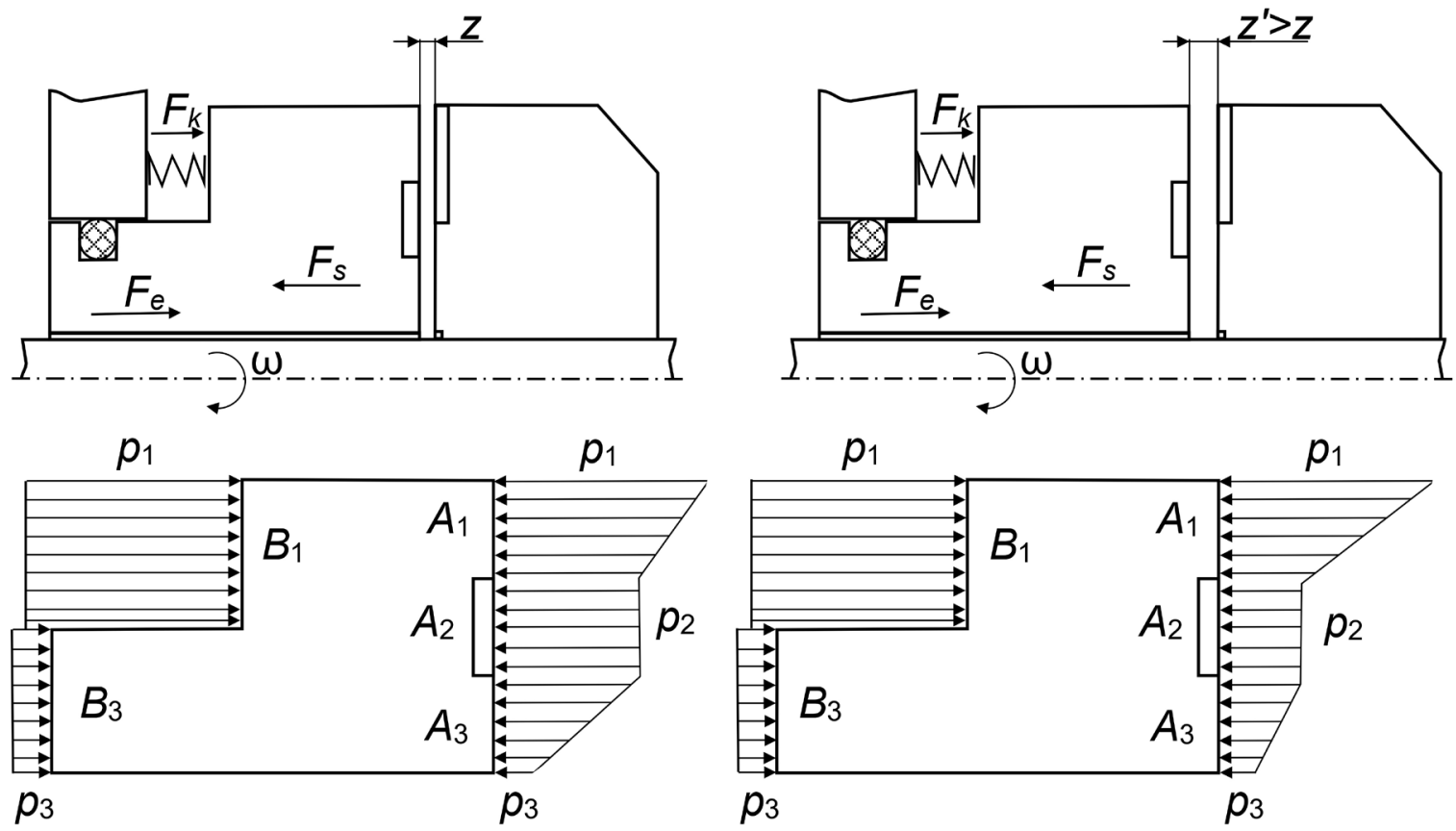

Figure 9 - Pressure distribution on the end surfaces of the axially movable rings 
Table - Computing the impulse seals characteristics

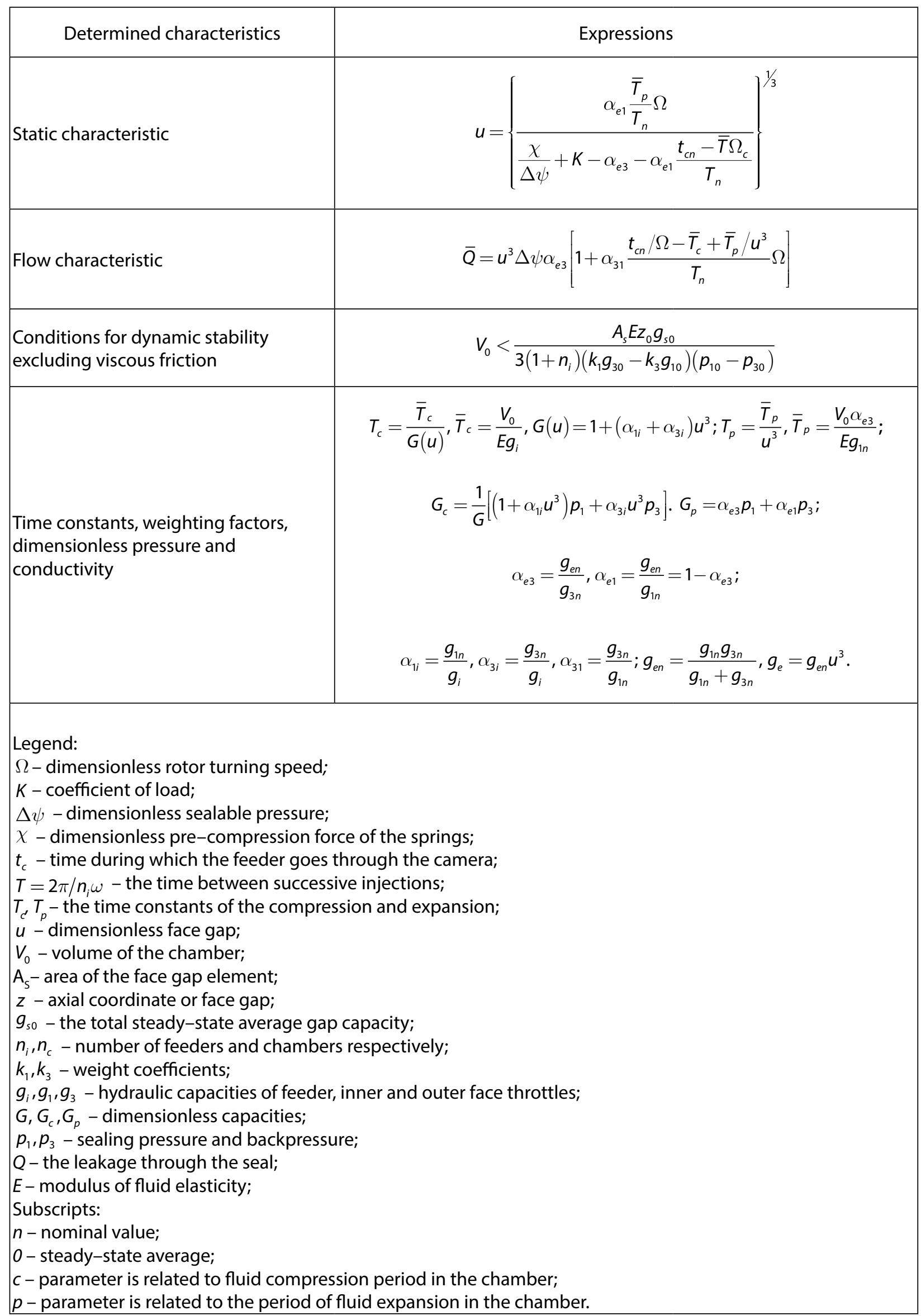




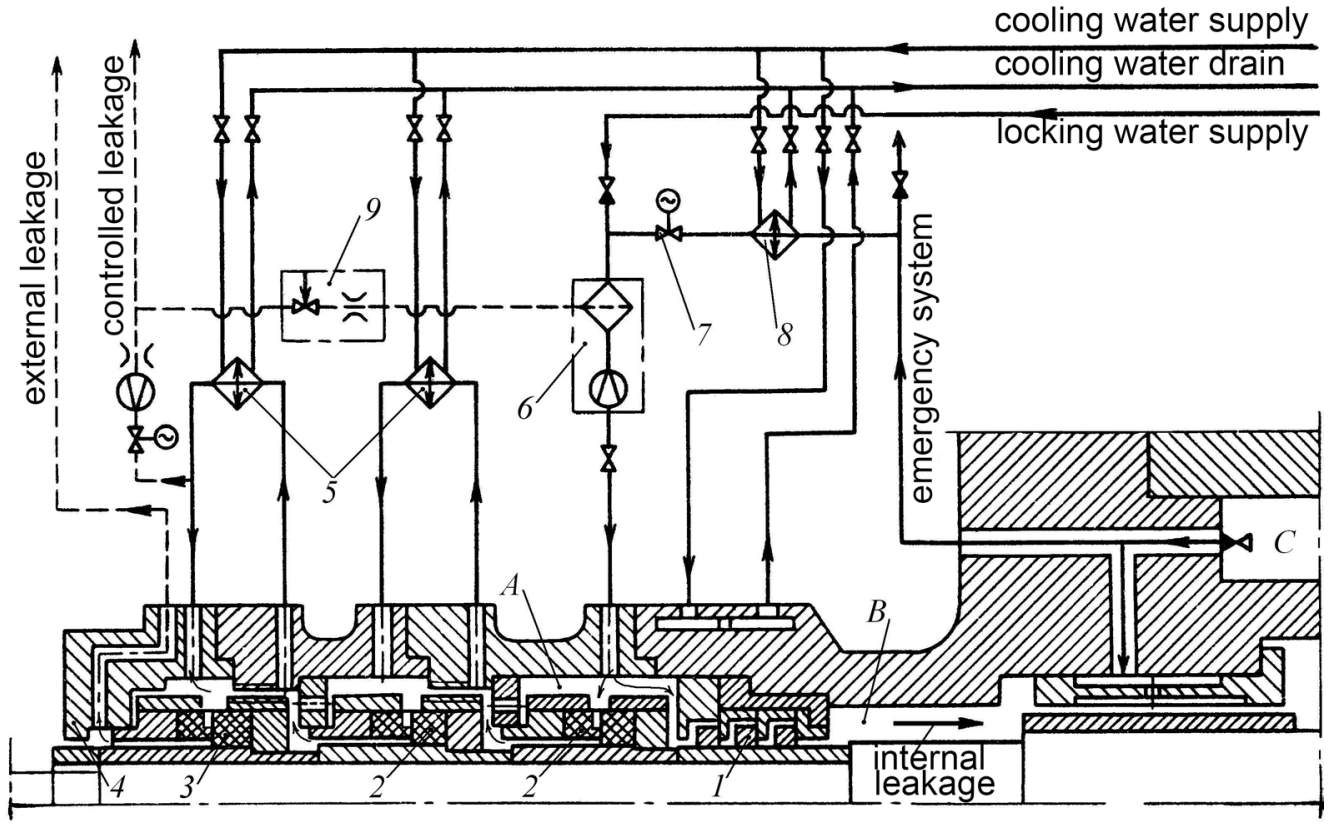

Figure 10 - Diagram of RCP shaft seal

\section{Sealing system of RCP shaft based on impulse seals}

The seal assembly (Figure 10) consists of internal 1 , main 2 , a closing 3 , and end 4 seal. Internal seal 1 , a set of three floating rings, separates the chamber $A$ for supplying cold sealing water from the sealed cavity of pump B. End contact bands are made on both sides on the floating rings. In the event of emergency pressure drop of the locking water, the rings operate at a pressure differential changed in the direction and the entire assembly provides the required tightness for $40 \mathrm{~s}$. Pressure differential across the inner seal is maintained within 0.1-0.5 MPa.

Main seal 2 consists of two stages of an impulse mechanical seal connected in series. In order to increase operation reliability of each stage, $98 \%$ of the total pressure differential is distributed equally between the first two stages using a dividing device. The same stage 3 serves as a closing seal, which should perform the functions of the main seal during a short period if one of the first two stages fails that allows the pump to be stopped normally. If leaks exceed the allowable value, the drain line is closed by an electric gate valve and the last seal stage will take full pressure differential. Since under normal operation, a pressure of about $0.5 \mathrm{MPa}$ is set before the last stage, its failure is unlikely. Mechanical seal 4 is a simple ring throttle.

The sealing system includes the line of locking water supply to chamber A by high-pressure feed pumps through hydrocyclone 6. Water throttled on the main seals 2 is cooled in heat exchangers 5. If the locking water supply system fails, the emergency system is activated: valve 7 opens and water from pump cavity through cooler 8 and hydrocyclone 6 enters chamber B providing normal long-term operation of the seal. If necessary, a part of the controlled leak can return to the loking water supply line through throttle device 9. Seal assembly operation measuring devices are remotely monitoring following parameters: locking water flow rate, controlled and external leaks, pressure and temperature in front of the seal stages, and pressure differential on the internal seal. In case of deviation of the mentioned parameters from the allowable values, an alarm or disconnection of the pumping unit are assumed.

\section{Conclusions}

The seal assembly is a complex system of internal, main, closing and emergency seals. Since each of them performs a specific function and operates in different conditions, the assembly is a synthesis of several seal types. The analysis of existing solutions shows that hydrostatic and mechanical seals with improved lubrication conditions are most widely used in RCP designs.

Compared to common mechanical seals, noncontacting mechanical seals with self-regulating gap as an automatic control systems have a number of undeniable advantages. In common mechanical seals, the friction power is proportional to the sealed pressure and circumferential speed, so their operability remains only in a narrow, estimated range of sealed pressure and rotational speed. In impulse seals, with an increase of the rotational speed, the end gap slightly increases, which limits friction power increase. 
By selection of the main geometrical parameters, it is possible to ensure the optimal value of the end gap and friction moment on sealing contact surfaces in a wide range of sealed pressure and rotor rotation frequency; therefore, their use is especially effective for high-speed machines. Impulse seals are reversible and reliably perform the function of stop seals, since during stoppage, there is no pressure in most chambers and external force significantly exceeds the force that opens the end gap.

Sealing systems based on impulse seals provide the required tightness, reliability and environmental safety under extreme conditions typical for RCP.

\section{References}

1. Martsinkovsky, V., Shevchenko, S. (2018). Pumps of nuclear power plants: calculation, design, operation. Private Fund "University Book Publishing House".

2. Kuznetsov, E., Tverdokhleb, l., Chernov, A. (2003). Modern shutter mechanical seals of centrifugal machines shafts. Current State and Prospects for the Development of Hydraulic Engineering in the XXI Century: Proceedings of an International Scientific and Technical Conference, 193-194.

3. Gudkov, S. (2007). Face mechanical seals with a friction pair hydrodynamic unloading. SSU Bulletin. Engineering, 2, 34-41. Retrieved from: https://essuir.sumdu.edu.ua/ handle/123456789/1977.

4. KSB (2017). Expertise you can trust: pumps, valves and services for nuclear power stations, 32. Retrieved from: https:/www.ksb.com/ blob/3628/64a52fa053f2b1514acc365ea37d0b93/nuclearpower-stations-data.pdf.

5. Nosowicz, J. (2001). Mechanical seals for the application in power plants. Seals and Sealing Technology in Machines and Devices, IXth International Conference, 77-84.

6. Minet, C., Brunetière, N., Tournerie, B. (2009). Mixed lubrication modelling in mechanical face seals. 2008 Proceedings of the STLE/ASME International Joint Tribology Conference, IJTC 2008, 477-479. doi: 10.1115/ijtc2008-71098.

7. Hayward, T. (2015). Nuclear. Pumps, motors \& services.

8. Flowserve (2018). Pump product portfolio, 96 . Retrieved from: https://www.flowserve.com/sites/default/files/2018-01/ fls-1001-ea4.pdf.

9. Gaft, J., Martsinkovskyy, V., Gromyko, B., Zahorulko, A. (2003). Design and calculation of mechanical seals with selfadjusting clearance. Proc. XVII Int. Conf. on Fluid Sealing, BHR Group, York, England, 505-520.

\section{Підвищення надійності й екологічної безпеки ущільнювань головних циркуляційних насосів AEC}

\author{
Шевченко С. С. ${ }^{1}$, Шевченко О. С. \\ 'Інститут проблем моделювання в енергетиці \\ ім. Г. Є. Пухова Національної академії наук \\ України, м. Київ, Україна \\ ${ }^{2}$ Сумський державний університет, м. Суми, \\ Україна
}

Виконано аналіз існуючих конструкцій ущільнювань систем роторів головних циркуляційних насосів АЕС. Визначено найбільш поширені конструктивні рішення ущільнюючих вузлів, які забезпечують необхідні надійність і ресурс в умовах високих тисків, температур і швидкостей ковзання, характерних для головних циркуляційних насосів, а також тенденції в напрямку їх удосконалення 3 метою підвищення герметичності й екологічної безпеки роботи.

Наведені конструкції імпульсних ущільнень із саморегульованим зазором, як найбільш перспективні вузли для герметизації валів насосів із високими параметрами. Запропонована розрахункова модель імпульсного ущільнення як системи автоматичного регулювання. Розроблено загальний порядок розрахунку імпульсних торцових ущільнень, що дозволяє вибором їх основних геометричних параметрів забезпечувати оптимальне значення торцового зазору і моменту тертя на ущільнюючих контактних поверхнях. Отримано вирази для побудови статичної та видаткової характеристик імпульсного торцового ущільнення, визначено умову його динамічної стійкості. Наведено систему ущільнення вала головного циркуляційного насоса, основними вузлами якого використані кілька ступенів імпульсних торцевих ущільнень із саморегульованим зазором.

Ключові слова: екологічна безпека, модель ущільнення, система автоматичного регулювання, статичний розрахунок, ущільнення вала ГЦН. 